\title{
Penerapan Pendidikan Karakter dalam Pembelajaran Membaca Dongeng pada Siswa Kelas 3 SDN Bukur 2
}

\section{Cerianing Putri Pratiwi}

Universitas PGRI Madiun

cerianing@unipma.ac.id

\begin{tabular}{ll}
\hline Informasi artikel & \\
\hline Sejarah artikel: & \\
Diterima & 20-I I-2017 \\
Revisi & 02-04-2018 \\
Dipublikasikan & Mei 20I8 \\
&
\end{tabular}

\section{Kata kunci:}

Pendidikan karakter

membaca

dongeng \begin{abstract}
ABSTRAK
Tujuan penelitian ini adalah (I) mendeskripsikan penerapan pendidikan karakter dalam perencanaan pembelajaran membaca dongeng (2) mendeskripsikan penerapan pendidikan karakter dalam pelaksanaan pembelajaran membaca dongeng (3) mendeskripsikan penerapan pendidikan karakter dalam penilaian pembelajaran membaca dongeng pada siswa kelas 3. Penelitian ini merupakan penelitian kualitatif deskriptif. Pada penelitian ini data yang dikumpulkan berupa fakta dan informasi penerapan pendidikan karakter dalam pembelajaran membaca dongeng pada siswa kelas $3 \mathrm{SD}$. Pada penelitian ini sumber datanya adalah guru dan siswa. Teknik pengumpulan data yang digunakan pada penelitian ini terdiri dari (a) dokumentasi, (b) observasi, (c) wawancara, dan (c) tes. Teknik analisis data dilakukan dengan menggunakan teknik analisis data model interaktif. Hasil dari penelitian menunjukkan bahwa pada pembelajaran membaca dongeng pada siswa kelas 3 SD pada tahap perencanaan, tahap pelaksanaan, dan tahap penilaian sudah mengintegrasikan nilai pendidikan karakter. Nilai-nilai pendidikan karakter yang terdapat pada pembelajaran yaitu nilai religius, tanggung jawab, kerja keras, percaya diri, berpikir kreatif, mandiri, santun, rasa ingin tahu, disiplin.
\end{abstract}

Key word:

character education

reading

fairy tales

\begin{abstract}
The purpose of this research is (I) to describe the application of character education in the planning of learning to read fairy tales (2) to describe the application of character education in the implementation of learning to read fairy tales (3) to describe the application of character education in the learning of fairy tale reading in grade 3 students. This research is a qualitative research descriptive. In this study the data collected in the form of facts and information on the application of character education in learning to read fairy tales in grade 3 elementary school students. In this study the data source is teachers and students. Data collection techniques used in this study consist of (a) documentation, (b) observation, (c) interviews, and (c) tests. Data analysis technique is done by using interactive data model analysis technique. The result of the research shows that in the learning of reading fairy tales in grade 3 elementary school students in the planning stage, implementation stage, and assessment phase have integrated character education value. The values of character education found in the values of religious, responsibility, hard work, self-confidence, creative thinking, independent, courteous, curiosity, discipline.
\end{abstract}

\section{Copyright (C) 2018 Universitas Ahmad Dahlan. All Right Reserved}

\section{Pendahuluan}

Pada saat ini, kemajuan zaman berkembang semakin cepat. Berbagai ilmu pengetahuan mudah diakses karena kemajuan teknologi yang semakin canggih. Hal tersebut dapat memudahkan seseorang dalam meningkatkan pengetahuan. Untuk memperoleh pengetahuan, informasi yang ingin diketahui seseorang dapat mengakses di mana saja dengan teknologi yang dimiliki.
Kemajuan zaman tersebut seharusnya tidak hanya meningkatkan kecerdasan intelektual tetapi juga meningkatkan kecerdasan moral dan karakter pada setiap individu. Akan tetapi, pada kenyataannya, perkembangan teknologi banyak yang menyalahgunakan. Penyalahan tersebut terlihat dari fenomena-fenomena yang terjadi dalam masyarakat seperti anak sekolah yang sering membolos karena kecanduan game, kekerasan seksual pada anak akibat sering melihat video pronografi, penculikan anak, dan pembunuhan. Fenomena tersebut menunjukan 
bahwa semakin terkikisnya kecerdasan moral dan karakter bangsa. Hal tersebut merupakan suatu kejadian yang sangat memprihatikan. Fenomenafenomena tersebut menunjukkan betapa pentingnya kecerdasan intelektual yang perlu dimbangi dengan karakter dan moral yang terpuji.

Kecerdasan moral sangat penting bagi setiap orang, dengan kecerdasan moral seseorang dapat dijadikan modal untuk menjalani hidup menjadi lebih baik. Hal itu dikarenakan dengan memiliki kecerdasan moral seseorang dapat membedakan yang benar dan yang salah. Hal tersebut sejalan dengan pendapat Borba (2008) bahwa kecerdasan moral yaitu kemampuan sesorang untuk bisa membedakan hal yang baik dan hal buruk yang terjadi dalam kehidupan seseorang tersebut sehingga ia dapat memahami serta menyadari yang baik dan yang buruk serta memahami etika sehingga memiliki pengangan untuk bertindak yang benar dan terpuji.

Melihat pentingnya kecerdasan moral pada seseorang, maka diperlukan penanaman karakter pada seseorang, agar seseorang tersebut memiliki kecerdasan moral. Pendidikan karakter akan lebih baik jika ditanamkan pada anak sejak dini. Kecerdasan moral sangat penting untuk dikembangkan, terutama dikembangkan pada anakanak. Hal itu agar anak-anak sebagai generai penerus bangsa dapat tumbuh menjadi pribadi bermoral sehingga bisa bertindak dengan benar dan terpuji. Oleh karena itu, penanaman karakter sangat penting jika ditanamkan sejak dini. Pentingnya penanaman pendidikan karakter pada anak sejak dini karena pada masa-masa tersebut anak usia dini memasuki masa emas perkembangan, di mana masa tersebut merupakan masa yang sangat baik dan dapat menentukan kualitas anak pada masa dewasanya. Maka pembentukan karakter anak usia dini merupakan titik awal dari pembentukan sumber daya manusia yang berkualitas.

Salah satu upaya yang dapat dilakukan untuk menanaman pendidikan karakter pada anak usia dini yaitu dengan cara memasukkan pada pendidikan formal. Pengembangan nilai-nilai karakter tidak dimuat secara khusus dalam sebuah mata pelajaran tertentu, akan tetapi disisipkan ke dalam setiap mata pelajaran di sekolah, agar siswa dapat berkembang menjadi pribadi yang berintelektualitas serta berkarakter. Menurut Asmani (20I I: 58-59) pendidikan karakter yang terintegrasi dalam pembelajaran merupakan pengenalan nilai-nilai dan internalisasi nilai-nilai ke dalam tingkah laku peserta didik melalui kegiatan pembelajaran. Oleh karena itu, seorang guru harus merancang perencanaan, pelaksanaan, dan evaluasi pembelajaran dengan menyisipkan nilai-nilai karakter.
Seorang guru merencanakan pembelajaran melalui Rencana Pelaksanaan Pembelajaran yang biasa disingkat dengan RPP. Dalam pembuatan RPP guru harus memperhatikan nilai-nilai karakter yang akan dicapai dan menuangkan dalam RPP. Pada pelaksanaan pembelajaran, seorang guru menjalankan apa yang sudah terencanakan. Setelah itu, pada proses evaluasi pembelajaran, seorang guru menilai ketercapaian pendidikan karakter yang terintegrasi dalam pembelajaran.

Penyisipan nilai-nilai karakter pada mata pelajaran diharapkan terjadi pada semua mata pelajaran, seperti pelajaran bahasa Indonesia. Pembelajaran bahasa Indonesia merupakan salah satu pelajaran yang dapat menyisipkan nilai-nilai karakter pada siswa. Hal itu sejalan dengan pendapat Syamsuddin (1986:2) menyatakan bahwa bahasa adalah tanda yang jelas dari kepribadian yang baik maupun yang buruk, tanda yang jelas dari keluarga dan bangsa, tanda yang jelas dari budi kemanusiaan. Berdasarkan pengertian tersebut, dapat diketahui bahwa bahasa dapat menunjukkan karakter seorang anak.

Pada pelajaran bahasa Indonesia ada empat aspek keterampilan yang diajarkan dalam siswa SD, yaitu keterampilan menyimak, berbicara, membaca, dan menulis. Salah satu keterampilan yang dapat disisipi pendidikan karakter yaitu keterampilan membaca dongeng. Saddhono dan Slamet (2014: IOI) menjelaskan bahwa membaca merupakan kegiatan memahami isi ide atau gagasan, baik yang tersurat, yang tersirat bahkan tersorot dalam suatu bacaan. Dongeng merupakan cerita yang banyak mengandung nilai moral dan sosial. Nilai-nilai tersebut berguna untuk membentuk karakter anak. Hal tersebut sejalan dengan pendapat Agus (2009:12) yang menyatakan bahwa meskipun dalam dongeng ceritanya tentang hal-hal yang bersifat khayal, tetapi dongeng mengandung nilai-nilai yang luhur. Oleh karena itu, pembentukan karakter anak di sekolah dapat dilakukan pembiasaan membaca dongeng.

Tujuan penelitian ini adalah mendeskripsikan penerapan pendidikan karakter dalam perencanaan pembelajaran membaca dongeng pada siswa kelas 3 SD (2) mendeskripsikan penerapan pendidikan karakter dalam pelaksanaan pembelajaran membaca dongeng pada siswa kelas 3 SD (3) mendeskripsikan penerapan pendidikan karakter dalam penilaian pembelajaran membaca dongeng pada siswa kelas $3 \mathrm{SD}$.

Menurut Majid dan Dian Andayani (2012:12) karakter adalah watak, sifat, atau hal-hal yang memang sangat mendasar yang ada pada diri seseorang. Hal-hal yang sangat abstrak yang ada pada 
diri seseorang. Pendidikan karakter juga dapat didefinisikan sebagai pendidikan yang mengembangkan karakter yang mulia (good character) dari peserta didik dengan mempraktikan dan mengajarkan nilai-nilai moral dan pengambilan keputusan yang beradap dalam hubungannya dengan Tuhannya (Samani dan Hariyanto, 2012:44). Raharjo (2010:233) menyatakan pendidikan karakter adalah proses pendidikan secara holistik yang menghubungkan dimensi moral dengan ranah sosial dalam kehidupan peserta didik sebagai pondasi bagi terbentuknya generasi berkualitas yang mampu hidup mandiri dan memiliki prinsip suatu kebenaran yang dapat dipertangungjawabkan. Kemdiknas (2010: 9-10) menyatakan nilai-nilai pendidikan karakter ada 18, yaitu: (I) religius, (2) jujur, (3) toleransi, (4) disiplin, (5) kerja keras, (6) kreatif, (7) mandiri, (8) demokratis, (9) rasa ingin tahu, (I0) semangat kebangsaan, (II) cinta tanah air, (I2) menghargai prestasi, (I3) bersahabat/ komunikatif, (I4) cinta damai, (I5) gemar membaca, (I6) sikap peduli lingkungan, (I7) peduli sosial, (I8) tanggung jawab.

Nilai-nilai karakter yang dikembangkan dalam pendidikan formal meliputi nilai kejujuran, tanggung jawab, hidup sehat, disiplin, kerja keras, percaya diri, berjiwa wirausaha, berpikir kreatif, logis, inovatif, mandiri, ingin tahu, cinta ilmu, santun, toleransi, demokratis, dan nasionalis (Asmani, 20II: 364I). Dari nilai-nilai karakter di atas, maka akan dipilah serta dipilih yang akan sesuai dengan karakteristik siswa SD. Menurut Ghazali (dalam Wahyuni, dkk., 20I2: I4-I5), dalam melakukan perencanaan pembelajaran pendidikan karakter, pendidik diminta untuk menganalisis kondisi pembelajaran, kendala pembelajaran, sumber materi pembelajaran, karakteristik siswa, dan kompetensi yang akan dicapai.

Keterampilan membaca pada umumnya diperoleh dengan cara mempelajarinya di sekolah. Saddhono dan Slamet (20I4: IOI) menjelaskan muara akhir kegiatan "membaca adalah memahami isi ide atau gagasan baik tersurat, tersirat bahkan tersorot dalam bacaan". Menurut Iskandarwassid dan Sunendar (20II: 246) "membaca merupakan kegiatan untuk mendapatkan makna dari apa yang tertulis dalam teks". Menurut Tarigan (2008: 9-I0) tujuan utama dalam membaca adalah untuk mencari serta memperoleh informasi, mencakup isi, memahami makna bacaan.

Dongeng merupakan kisah pusaka yang pengenalannya secara turun temurun dari nenek moyang dan secara merata dikenal oleh masyarakat. Dongeng memiliki berfungsi untuk menyampaikan ajaran-ajaran moral kepada pendengarnya dan juga untuk menghibur. Hana (20II: I4) berpendapat bahwa dongeng yaitu cerita rekaan, tidak nyata, atau fiksi. Hampir sama dengan pendapat Agus (2008), yang menyatakan bahwa dongeng merupakan cerita rakyat yang tidak benar-benar terjadi atau bersifat khayal dan tidak terikat waktu ataupun tempat serta tokoh ceritanya dapat berupa manusia, binatang, dan makhluk halus.

\section{Metode}

Penelitian ini merupakan penelitian kualitatif, di mana pada penelitian ini menyajikan data yang berupa kata-kata dan bahasa. Penelitian ini merupakan penelitian deskriptif. Tujuan utama dilakukan penelitian deskriptif yaitu menggambarkan fakta secara sistematis dan karakteristik objek atau subjek yang diteliti secara tepat. Penelitian deskriptif ini bertujuan untuk mendeskripsikan suatu keadaan, melukiskan, serta menggambarkan penerapan pendidikan karakter dalam pembelajaran membaca dongeng pada siswa kelas $3 \mathrm{SD}$.

Data pada penelitian ini yaitu catatan peneliti. Data yang dikumpulkan pada penelitian ini berupa fakta dan informasi penerapan pendidikan karakter dalam pembelajaran membaca dongeng siswa kelas 3 SDN Bukur 2 . Penelitian ini sumber data yang digunakan yaitu guru dan siswa.

Teknik pengumpulan data yang digunakan pada penelitian ini terdiri dari (a) observasi, (b) wawancara, dan (c) tes, (d) dokumentasi. Setelah melakukan pengumpulan data. Menurut Wiyono dan Burhannuddin (2007: 90) analisis data adalah proses penyusunan data agar bisa ditafsirkan dan disimpulkan. Data yang telah dikumpulkan harus diperiksa keabsahannya. Tiangulasi adalah teknik pemeriksaan keabsahan data yang memanfaatkan sesuatu yang lain di luar data itu untuk keperluan pengecekan atau sebagai pembanding terhadap data itu (Moleong; 2007: 330). Pada penelitian ini, cara yang digunakan untuk memperoleh kebenaran yaitu dengan menggunakan triangulasi teori. Teknik analisis data pada penelitian ini adalah analisis data kualitatif. Teknik analisis data dilakukan dengan menggunakan teknik analisis data model interaktif. Menurut Miles dan Huberman (1992: 19-20) ada tiga hal utama dalam analisis data model interaktif yaitu reduksi data, penyajian data, dan penarikan kesimpulan atau verifikasi.

\section{Hasil dan pembahasan}

Hasil penelitian dan pembahasan ini memaparkan deskripsi penerapan pendidikan karakter dalam pembelajaran membaca dongeng siswa kelas 3 SDN Bukur 2. Pada hasil dan 
pembahasan ini yang akan dideskripsikan yaitu meliputi perencanaan, pelaksanaan, dan evaluasi pendidikan karakter pada pembelajaran membaca dongeng.

Pengambilan data dilakukan di SDN Bukur 02, Kecamatan Jiwan, Kabupaten Madiun. Pembelajaran ini dilaksanakan pada siswa kelas 3 dengan standar kompetensi memahami teks dengan membaca nyaring, membaca intensif, dan membaca dongeng, sedangkan kompetensi dasar yang dipakai yaitu menceritakan isi dongeng yang dibaca.

Berdasarkan hasil observasi, wawancara, dan analisis dokumen dapat dinyatakan bahwa pendidikan karakter dalam pembelajaran membaca dongeng sudah diterapkan. Pada perencanaan sudah terkandung nilai-nilai karakter. Nilai-nilai pendidikan karakter sudah dicantumkan dalam perencanaan pembelajaran dengan tujuan agar tidak terjadi tumbang tindih terhadap nilai karakter yang akan dicapai. Hal itu hampir sama dengan pendapat Wibowo (2012) bahwa nilai-nilai karakter yang akan dicapai dicantumkan dalam silabus dan RPP yang dibuat oleh pendidik.

Perencanaan dalam pembelajaran menulis cerita tertuang melalui silabus dan RPP. Berdasarkan hasil wawancara, guru menyatakan bahwa silabus dibuat setiap satu semester, dan dibuat pada awal semester, sedangkan RPP dibuat oleh guru pada saat akan mengajar. Nilai-nilai karakter selalu dicantumkan pada silabus dan RPP. Pada saat membuat perencanaan pembelajaran, guru memilah serta memilih nilai-nilai karakter yang cocok dengan karakteristik siswa. Guru selalu menyesuaikan pemilihan nilai karakter dengan kebutuhan siswa. Guru terus berusaha agar nilainilai karakter tetap ada pada perencanaan pembelajaran sehingga siswa dapat memahami nilainilai karakter.

Pada analisis dokumen yaitu analisis silabus dan RPP, maka dalam perencaan pembelajaran membaca dongeng yang disusun oleh guru sudah tampak nilainilai karakter yang meliputi nilai religious, tanggung jawab, kerja keras, percaya diri, berpikir kreatif, mandiri, santun, rasa ingin tahu, disiplin. Semua nilai-nilai pendidikan karakter tersebut nilai-nilai karakter yang dikembangkan dalam pendidikan formal. Hal itu sejalan dengan pendapat Asmani (20II: 36-4I) yang menyatakan bahwa nilai-nilai karakter yang dikembangkan dalam pendidikan formal meliputi nilai kejujuran, tanggung jawab, hidup sehat, disiplin, kerja keras, percaya diri, berjiwa wirausaha, berpikir kreatif, logis, inovatif, mandiri, ingin tahu, cinta ilmu, santun, toleransi, demokratis, dan nasionalis.
Pelaksanaan pendidikan karakter pada pembelajaran membaca dongeng di SDN Bukur 2, sudah menerapkan nilai-nilai karakter. Berdasarkan hasil observasi dan wawancara dengan guru, sudah menyatakan bahwa pelaksanaan pembelajaran membaca dongeng pada siswa kelas 3 sudah mengandung nilai-nilai karakter yang sesuai dengan perencanaan. Penanaman nilai pendidikan karakter siswa kelas 3 ini juga diberikan dengan peneladanan guru. Hal itu dikarenakan salah satu peran guru yaitu sebagai model bagi siswa, yang artinya guru itu merupakan contoh atau suri tauladan bagi siswa. Hal itu selajan dengan pendapat Samani dan Hariyanto (2012:4I) bahwa pendidikan karakter adalah hal posisif apa saja yang dilakukan guru dan berpengaruh kepada karakter siswa yang diajarkannya. Berdasarkan observasi, pelaksanaan pembelajaran membaca dongeng siswa kelas 3 SDN Bukur 2 ini sudah mengaktualisasikan pendidikan karakter. Integrasi nilai pendidikan karakter dilakukan melalui kegiatan pembelajaran yang terdiri atas kegiatan pendahuluan, kegiatan inti, dan kegiatan penutup.

Pada saat kegiatan pendahuluan guru sudah mengintegrasikan nilai karakter yaitu nilai santun. Hal itu terlihat ketika guru membuka pembelajaran dengan ramah dan dengan senyum yang diberikan pada siswa. Pada kegiatan pendahuluan, juga tampak nilai religius, hal tersebut tampak pada saat guru dan siswa ngucapkan doa sebelum memulai pembelajaran. Tidak hanya itu, pada kegiatan pendahuluan juga masih ditemukan nilai karakter yaitu rasa ingin tahu. Nilai karakter ini muncul ketika guru memberikan apersepsi. Guru memberikan pertanyaan-pertanyaan yang memancing rasa ingin tahu siswa. Pada kegiatan pendahuluan ini juga tampak nilai disiplin, karena siswa terbib disiplin mengikuti pembelajaran.

Pada tahap kegiatan inti juga sudah terlihat nilai-nilai karakternya. Beberapa nilai karakter yang muncul yaitu ingin tahu, tanggung jawab, disiplin, kerja keras, percaya diri, berpikir kreatif. Berdasarkan hasil observasi, hal itu sesuai dengan apa yang ada pada perencanan yang tersusun pada silabus dan RPP.

Pada saat dilaksanakannya observasi pelaksanaan pembelajaran membaca dongeng, pada saat guru menjelaskan materi tentang dongeng, siswa tampak antusias dalam mendengarkan penjelasan guru. Setelah selesai diberi penjelasan, siswa tampak ingin tahu dengan hal-hal yang berhubungan dengan dongeng, misalnya menanyakan dongeng apa yang terkenal. Guru juga menjelaskan unsur-unsur instrinsik cerita. Siswa terlihat cukup antusias dengan materi yang disampaikan guru. Selain itu, siswa juga tampak penasaran dan ingin tahu ketika guru memberikan lembar kertas yang berupa bacaan 
dongeng. Siswa tampak ingin tahu dengan isi ceritanya. Hal tersebut menunjukkan bahwa sudah terlihat nilai karakter ingin tahu.

Setelah guru membagikan lembar bacaan dongeng, guru mengarahkan siswa untuk membaca dongeng tersebut. Dongeng yang diberikan kepada siswa yaitu "Asal-usul Candi Prambanan". Siswa membaca dongeng dengan tenang dan tertib, mereka terlihat cukup disiplin dalam menjalankan instruksi dari guru. Hal tersebut menunjukkan nilai karakter disiplin sudah tampak pada kegiatan inti. Setelah siswa selesai membaca, guru mengarahkan siswa untuk menemukan tokoh-tokoh dalam dongeng, menemukan tema, latar, serta amanat pada dongeng. Tugas tersebut berupa tugas individu, di mana siswa akan bekerja mandiri. Hal tersebut menunjukkan nilai karakter mandiri. Setelah itu, siswa diminta guru untuk menemukan pokok-pokok pikiran dari dongeng tersebut. Siswa mulai mengerjakan tugas dari guru dengan rasa tanggungjawab. Mereka menyelesaikan tugas sesuai dengan waktu yang telah ditentukan. Setelah itu guru memberikan tugas siswa untuk menuliskan kembali dongeng yang dibaca. Pada saat mengerjakan tugas ini siswa harus berpikir kreatif dan bekerja keras dalam menyusun kalimatkalimat pada cerita. Hal tersebut tampak bahwa pada kegiatan inti ini juga tampak nilai tanggungjawab dan berpikir kreatif. Setelah selesai menuliskan kembali, siswa diminta oleh guru untuk menceritakan isi dongeng yang telah dibaca. Siswa menceritakan isi dongeng yang sudah dibaca di depan kelas. Siswa menceritakan isi dongeng dengan rasa percaya diri. Semua siswa berani menceritakan isi dongeng yang telah dibaca di depan kelas. Hal tersebut menunjukkan bahwa nilai karakter percaya diri sudah tampak. Setelah semua siswa menceritakan isi dongeng, guru dan siswa mengulas tentang dongeng yang telah dibaca. Guru menjelaskan kepada siswa bahwa terdapat beberapa nilai karakter pada dongeng tersebut yaitu santun, kerja keras, dan percaya diri. Guru juga menjelaskan mana perbuatan yang harus diteladani dan mana perbuatan yang tidak terpuji dan harus dihindari perbuatan tersebut agar memiliki sikap terpuji.

Kegiatan pada pelaksanakan selanjutnya yaitu kegiatan penutup. Berdasarkan hasil observasi, kegiatan penutup pembelajaran meliputi kegiatan evaluasi pembelajaran, doa, dan salam penutup. Evaluasi dilakukan untuk mengetahui hasil belajar siswa. Siswa diberikan tugas berupa pilihan ganda yang sudah disediakan guru. Tugas tersebut ditulis pada kertas yang dibagikan kepada siswa. Setelah itu, guru menugasi salah satu siswa untuk memimpin berdoa untuk menanamkan nilai religius.
Berdasarkan hasil wawancara, penilaian pembelajaran membaca dongeng siswa kelas 3 SDN Bukur 2 tercermin melalui aspek kognitif, aspek afektif, aspek psikomotor. Penilaian dilakukan dengan cara tes dan non tes. Hal ini sejalan dengan pendapat Kesuma, dkk. (20II: I38-I39), yang menyatakan bahwa penilaian pendidikan karakter dapat dilakukan melalui tes ataupun non-tes. Aspek kognitif yang dilakukan dengan memberikan tes kepada siswa. Tes tersebut berupa pemberian soal pilihan ganda pada siswa. Pada aspek afektif, penilaian dilakukan dengan menggunakan observasi pada saat pembelajaran berlangsung. Penilaian pendidikan karakter dilakukan untuk mengetahui karakter yang dimiliki siswa. Hal tersebut sesuai dengan pendapat menurut Kesuma, dkk. (20II) bahwa penilaian pendidikan karakter bertujuan untuk mengetahui kemajuan karakter yang dimiliki oleh peserta didik, mengetahui kekurangan, dan kelebihan perencanaan pembelajaran serta mengetahui efektivitas proses pembelajaran. Pada aspek psikomotor, penilaian dilakukan dengan tes keterampilan menceritakan isi dongeng yang sudah dibaca.

\section{Simpulan}

Berdasarkan hasil penelitian dan pembahasan maka dapat disimpulakn bahwa pendidikan karakter dalam pembelajaran membaca dongeng pada siswa kelas 3 SDN Bukur 2, kecamatan Jiwan, kabupaten Magetan sudah terintegrasi pada perencanaan pembelajaran, pelaksanaan pembelajaran, dan penilain hasil pembelajaran. Pada tahap perencanaan nilai-nilai karakter sudah tercantum pada perencanaan pembelajaran yang termuat pada silabus dan RPP yang dibuat oleh guru. Pada RPP sudah tertuang nilai-nilai karakter nilai religious, tanggung jawab, disiplin, kerja keras, percaya diri, berpikir kreatif, mandiri, ingin tahu, santun. Pada pelaksanaan, nilai-nilai karakter yang muncul yaitu nilai santun, religious, ingin tahu, tanggung jawab, disiplin, kerja keras, percaya diri, berpikir kreatif. Penilaian pembelajaran membaca dongeng siswa kelas 3 SDN Bukur 2 tercermin melalui aspek kognitif, aspek afektif, aspek psikomotor. Penilaian dilakukan dengan cara tes dan non tes.

Diharapkan dengan adanya pendidikan karakter yang diselipkan pada pembelajaran membaca dongeng, maka dapat keseimbangan antara kecerdasan intelektual dengan kecerdasan moral. Siswa dapat berkarakter dan memiliki moral yang terpuji, sehingga akan terbentuk manusia yang cerdas dan bermartabat. Disarankan kepada guru untuk selalu member teladan yang baik kepada siswa serta memasukkan nilai-nilai karakter dalam pembelajaran. 


\section{Persantunan}

Artikel ini disusun atas dorongan dan dukungan dari berbagai pihak. Ucapan terimakasih disampaikan kepada Universitas PGRI Madiun dan teman-teman sejawat. Ucapan terima kasih juga disampaikan kepada tim editorial Bahastra Pendidikan Bahasa dan Sastra Indonesia Universitas Ahmad Dahlan yang telah memberikan ruang untuk penerbitan artikel ini. Semoga artikel ini dapat memberikan kontribusi dalam pembelajaran terutama dalam kegiatan literasi kritis.

\section{Daftar Pustaka}

Agus. 2009. Tips Jitu mendongeng. Yogyakarta: Kanisius.

Asmani, Jamal Ma'mur. 20I I. Buku Panduan Internalisasi Pendidikan Karakter di Sekolah. Yogyakarta: Diva Press.

Borba, M. 2008. Membangun Kecerdasan Moral. Gramedia Pustaka Utama.

Hana, Jasmin. 20II. Terapi Kecerdasan Anak dengan Dongeng. Yogyakarta: Berlian Media.

Iskandarwassid dan Dadang Sunendar. 2008. Strategi Pembelajaran Bahasa. Bandung: PT Remaja Rosdakarya.

Kemdiknas. 20I0. Desain Induk Pendidikan Karakter. Jakarta: Kementerian Pendidikan Nasional.

Kesuma, Dharma dkk. 20II. Pendidikan Karakter Kajian Teori dan Praktek di Sekolah. Bandung: PT Remaja Rosdakarya.

Majid, Abdul dan Dian Andayani. 2012. Pendidikan Karakter Perspekstif Islam. Bandung: Remaja Rosdakarya.

Miles, Mattew B. dan A. Michael Huberman. Analisis Data Kualitatif. Jakarta: Universitas Indonesia.

Moleong, Lexy J. 2007. Metodologi Penelitian Kualitatif. Bandung: Remaja Rosdakarya.

Raharjo, Sabar Budi. 20I0. Pendidikan Karakter Sebagai Upaya Menciptakan Akhlak Mulia. Ina. J. Dikbud, I6(3): 229-238).

Saddhono Kundharu dan Slamet Y. 20I4. Pembelajaran Keterampilan Berbahasa Indonesia. Yogyakarta: Graha Ilmu.

Samani, Muchlas dan Hariyanto. 2012. Konsep dan Model Pendidikan Karakter. Bandung: Remaja Rosdakarya.

Syamsuddin, A.R. 1986. Sanggar Bahasa Indonesia. Jakarta: Universitas Terbuka.

Tarigan, Henry Guntur. 2008. Membaca Sebagai Suatu Keterampilan Barbahasa. Bandung: Angkasa.

Wahyuni, Sri, dkk. 2012. Perencanaan Pembelajaran Bahasa Berkarakter. Bandung: PT. Refika Aditama.

Wibowo, Agus. 2012. Pendidikan Karakter. Yogyakarta: Pustaka Pelajar.
Wiyono, Bambang Budi dan Burhanuddin. 2007. Metodologi Penelitian (Pendekatan Kuantitif, Kualitatif, dan Action Research). Malang: FIP Universitas Negeri Malang. 